\title{
Dossiê
}

\section{Democracia, Estado e Governo: breves considerações sobre o Brasil}

Antonio Carlos Dias Junior

Doutor em Sociologia pela Unicamp. Professor do Departamento de Ciências Sociais na Educação e do Programa de Pós-Graduação em Educação da Faculdade de Educação da Unicamp.

Robert Bonifácio

Doutor em Ciência Política pela Universidade Federal de Minas Gerais (UFMG).

O tema do dossiê - Democracia, Estado e Governo - nos impõe uma reflexão sobre os desenvolvimentos recentes do Estado brasileiro, em especial sobre a qualidade e o alcance da governança democrática, da legitimidade política e do desenvolvimento global de nossa sociedade. Mais do que simplesmente considerar os limites e as possibilidades resultantes dos processos eleitorais, faz-se necessário questionar a própria natureza do que se entende por democracia participativa, com vistas à constituição de uma cultura na qual o espaço público seja, de fato, ocupado pelos sujeitos de direito, e no qual as políticas públicas governamentais sirvam de fomento para a diminuição das desigualdades, num diálogo permanente com a sociedade civil.

A partir de um rápido panorama do desenvolvimento econômico-social recente do Brasil, podemos observar que a pobreza absoluta (até US\$1,90 por dia) caiu em $64 \%$ no período 2001 a 2013 , passando de $13,6 \%$ para $4,9 \%$ da população. O país nesse período apresentou algumas das taxas de declínio nos índices de pobreza mais expressivas entre os países em desenvolvimento. Também é verdade que, por outro lado, boa parte do crescimento econômico resultante do acesso aos bens de consumo duráveis - via aumento da renda das famílias - mostrouse limitado por não ser acompanhado na mesma proporção pela oferta de serviços públicos essenciais. O bom desempenho da economia brasileira na primeira década dos anos 2000, muito em função da dinâmica da economia mundial (em especial da economia chinesa e sua demanda por commodities), aliado a índices crescentes de oferta de emprego e de crédito, acabaram por desenhar um panorama falaciosamente favorável, e que hoje se apresenta na forma de recessão, desemprego e inflação.

Nas duas últimas décadas, o Índice de Desenvolvimento Humano (IDH), que mede conjuntamente dados de renda (PIB per capta), educação (taxas de alfabetização e de escolarização) e saúde (expectativa de vida ao nascer) apresentou uma melhora da ordem de $47,5 \%$. As taxas de mortalidade infantil, embora ainda alarmantes, caíram praticamente pela metade no período 20002015. ${ }^{1}$ Nesse quesito, por exemplo, atingimos as "metas do milênio" sugeridas pela Organização das Nações Unidas (ONU). No que se refere aos dados educacionais, observamos na última

\footnotetext{
${ }^{1}$ Taxa de Mortalidade Infantil no Brasil (por 1000 nascidos vivos): de 29,02 em 2000 para 13,82 em 2015. Dados oficiais do Instituto Brasileiro de Geografia e Estatística (IBGE). Disponível em

http://brasilemsintese.ibge.gov.br/populacao/taxas-de-mortalidadeinfantil.html. Acessado em 30/11/2015.
}

década avanços significativos, como a ampliação do número de matrículas e das taxas de frequência à escola em todos os níveis, bem como o combate ao analfabetismo. ${ }^{2}$ Por outro lado, questões estruturais historicamente não resolvidas, como o acesso à terra $e$ à moradia, a melhoria nas condições básicas de existência, assim como a brutal concentração de renda - entre outras importantes questões - representam desafios perenes para o conjunto de nossa sociedade.

Os 30 anos de redemocratização (ou 26 anos, se considerarmos como marco as eleições de 1989) - o maior período de estabilidade democrática na história do país - têm se mostrado bastante dinâmicos em todas as esferas da vida em sociedade, em especial no que se refere à arena política, tal como se espera de uma sociedade livre e plural. Promulgada uma nova Constituição em 1988 - prontamente alcunhada de "cidadã" - e transcorridos sete pleitos presidenciais consecutivos, percebemos que algumas questões e eventos alcançam estatura nacional, atravessando diversos setores da sociedade e fomentando posições antagônicas e apaixonadas.

No campo da ação governamental, certamente a política pública mais expressiva e também a mais discutida nas últimas décadas é o Programa Bolsa Família (PBF). Aproximadamente 14 milhões de famílias, espalhadas por mais de 5 mil municípios, são beneficiárias, segundo os dados disponibilizados pelo Ministério do Desenvolvimento Social e Combate à Fome. Trata-se de uma política de cunho distributivo que assegura recursos financeiros a famílias em situação de pobreza, desde que os beneficiários cumpram determinadas contrapartidas nas áreas de saúde e de educação.

Muito se discute sobre os efeitos práticos dessa política. Por um lado, há os que destacam que a transferência de renda per se contribui para um comportamento acomodado por parte do beneficiário, não o instigando à superação das adversidades. Adicione-se a isso a consideração de que o PBF teria um caráter assistencialista, incapaz de favorecer a real superação do problema que ataca. O ditado popular "dar o peixe, mas não ensinar a pescar" ilustra bem este tipo de argumentação. Por outro

\footnotetext{
2 Houve uma diminuição de 4,3 pontos percentuais (que representa 2,5 milhões de pessoas) no número de analfabetos com 15 anos ou mais no período de 2001 a 2014 . Contudo, atualmente, ainda $8,3 \%$ dos brasileiros são analfabetos (13,2 milhões de pessoas), segundo os dados da Pesquisa Nacional por Amostra de Domicílios (Pnad) do IBGE, de 2014. Disponível em:

http://www.ibge.gov.br/home/estatistica/indicadores/trabalhoerendimento/pn ad continual. Acessado em 30/11/2015.
} 
lado, há vozes que destacam a capacidade do programa de minar a desigualdade existente no país e de possibilitar um mínimo de bem-estar e inclusão às populações marginalizadas. Também faz parte do coro favorável ao PBF aqueles que destacam serem os programas de transferência de renda uma importante fonte de desenvolvimento da economia local, bem como de dinamização geral da economia do país.

O que os brasileiros pensam a respeito disso tudo? É possível termos um retrato a respeito a partir de dados do "Barômetro das Américas"3. Embora não se tenha dados suficientes para uma adequada comparação no tempo, dentre os disponíveis observamos certa ambivalência na percepção do brasileiro em relação ao PBF. Se, por um lado, numa pesquisa aplicada em 2010 , aproximadamente $60 \%$ dos entrevistados pensavam que o governo deveria ampliar o número de famílias beneficiadas, também há indicações em direção oposta. Em 2012, cerca de 85\% dos entrevistados afirmavam serem contrários a aumento de impostos visando mais investimento no PBF e, em 2014, aproximadamente $55 \%$ dos entrevistados posicionaram-se em gradações próximas à concordância com a ideia de que os beneficiários se acomodam por receberem o benefício ${ }^{4}$. As contradições nas discussões científicas e políticas e o posicionamento ambivalente da sociedade sobre 0 PBF certamente sustentarão o tema do combate à miséria na agenda política por muitos anos.

No que diz respeito à legitimidade democrática, o Brasil tem se saído bem em importantes eventos que "testam" o apego de seus cidadãos ao regime e princípios democráticos. Em 1992, poucos anos após a eleição do primeiro Presidente da República desde o regime militar (1964-1985), uma multidão foi às ruas pedir o impedimento do eleito, Fernando Collor de Mello. O Congresso Nacional seguiu a tendência das ruas e cassou seu mandato, sem ter como consequência qualquer ruptura institucional. O fim da Era FHC (1995-2002) e a sucessiva eleição pacífica de um opositor ao seu projeto político também pode ser considerado um evento no qual a sociedade civil e a classe política nacional mostraram um elevado compromisso com as instâncias políticas democráticas. Ressalte-se, sobretudo, o fato do opositor eleito, Luiz Inácio Lula da Silva, ser um líder operário de origem popular, fato inédito e inusitado tendo em vista nossa história política.

A onda de protestos que se iniciou em 2013 e também se repetiu em 2014 e 2015 expressam um sinal positivo da maturidade democrática do país. Motivados por diferentes razões insatisfação com a corrupção generalizada, clamor por melhorias nos serviços públicos e cobrança de um comportamento mais ético e probo dos políticos - esses protestos contestaram a

\footnotetext{
3 O "Barômetro das Américas" é um conjunto de pesquisas de opinião aplicadas em dezenas de países das Américas, com amostras representativas das populacões. É desenvolvido pelo Latin American Public Opinion Project (LAPOP) da Vanderbilt University. Informações disponíveis em: http://www.vanderbilt.edu/lapop/. Acessado em 30/11/2015.

${ }^{4}$ Respostas de 1 a 3 numa escala que vai até 7 . O valor 1 expressa a máxima concordância com a ideia e o valor 7 , a máxima discordância com a seguinte frase: Mudando de assunto de novo, algumas pessoas dizem que beneficiários do programa Bolsa Família ficam acomodados ao receber seu benefício. Até que ponto concorda ou discorda desta frase?
}

qualidade das instituições e atores políticos. Embora tenham-se observado práticas violentas e a existência de grupos minoritários saudosos do regime militar, entendemos que esses protestos aprimoraram uma cultura política pró-democrática: por meio de ações voluntárias e, em boa parte, apartidárias, que vocalizaram múltiplas demandas, os brasileiros expressaram um tom crítico sem, contudo, contestarem a permanência do regime democrático.

Nossa expectativa é a de que as importantes contribuições, de diversos autores, contidas neste dossiê possam fomentar o debate crítico e, dessa forma, contribuir para a consolidação das ainda jovens estruturas democráticas brasileiras. $O$ desafio é grande, a julgar pelo que podemos cotidianamente observar nos noticiários que relatam a atuação de boa parte de nossos representantes eleitos e suas respectivas condutas pouco afeitas aos interesses a res publica. 